\title{
Late Pleistocene Crocuta crocuta spelaea in Bulgaria: distribution and history of research (Carnivora: Hyaenidae)
}

\author{
Късноплейстоценската западна пещерна хиена (Crocuta crocuta spelaea) \\ в България: разпространение и история на изследванията (Carnivora: Hyaenidae)
}

\section{Zlatozar BOEV}

National Museum of Natural History, Bulgarian Academy of Sciences, Blvd. Tsar Osvoboditel 1, 1000 Sofia, Bulgaria; boev@nmnhs.com

received on 26 November 2020

\begin{abstract}
The paper summarizes all scattered data from the last 116 years on the distribution of the Late Pleistocene cave hyena in Bulgaria, a part of them unpublished. Data from 24 fossil sites (Middle Pleistocene - Late Pleistocene) in the country are presented. The fossil record in Bulgaria proves the wide distribution of the species in the karst areas of the low-mountain regions of the country. Its Pleistocene localities are concentrated in the Predbalkan Mts. (83\%), Strandja Mts. (8\%), Western Rhodopes Mts. (4\%) and southern Dobruja Plain (4\%). They are situated at the altitudes between 136 and $1250 \mathrm{~m}$ a.s.1., about $75 \%$ of them at $136-400 \mathrm{~m}$ a. s. 1 . All (except one) Bulgarian sites represent former human dwellings, which indicates competition between man and this carnivore for the cave spaces.
\end{abstract}

Key words. Cave hyena, large carnivores, Quaternary mammals, history of wildlife, Balkans.

\section{INTRODUCTION}

The Late Pleistocene western cave (spotted) hyena, Crocuta crocuta spelaea (Goldfuss, 1823), is one of the iconic Quaternary species of the European megafauna. This impressive carnivore has been subject of a number of special studies in several countries and territories: Crimea (BARYŠNIKOv 1995), Czechia (DiedRICH \& ŽÁK 2006), Jordan (KEMPE et al. 2006), Italy (Stiner 2004), Russia (GričAn \& Ovodov 1978, Baryshnikov \& Vereshchagin 1996), and Serbia (DimitriJević 2011). It is believed that the African spotted hyena migrated into Europe not earlier than 3.5 Ma (Rohland et al. 2005). NAGEL et al. (2004) suggested that the species entered Europe much later, ca. 0.5 Ma. In Quaternary Europe it experienced an increase in body size (Bergmann's rule). The earliest fossil record of C. crocuta is dated 990,000 years BP (HoleKamp \& Kolowski 2009).

In Europe, the Late Pleistocene spotted hyena and the steppe lion, Panthera leo spelaea (Goldfuss, 1810), were top predators and often competed for prey in the same way as they do today in the African savannahs (DiEDRICH 2014). In the Far East, C. c. spelaea was replaced by an even much more carnivorous cousin - the eastern (supreme) cave hyena (C. c. ultima Matsumoto, 1915), which reached southern China and Thailand (SURAPRASIT et al. 2015). This subspecies was more adapted to life in open habitats and was less associated with caves in comparison to the western cave hyena, C. c. spelaea. 
The Late Pleistocene range of the western cave hyena covered most of Europe, western and northern Asia, Russian Plain, Crimea, Caucasus, Ural Mts. and (?) southern Far East of Russia (Gromov \& Baranova 1981). The western cave hyena hunted the same ungulates as the primitive man did. In Europe it also competed with man for the caves as a suitable and reliable shelter and dwelling space.

\section{MATERIAL AND METHODS}

I tried to gather all data (published and unpublished) on the former distribution of the Pleistocene western cave hyena (Crocuta crocuta spelaea) in the present territory of Bulgaria. For each site I present as complete data as possible on the age, years and leaders of excavations, and the reference of the original published information (Table 1). The great majority of hyenid bone/teeth findings (except those from the Borikovska Cave) came from the excavated archeological sites of the prehistoric human cave dwellings.

Thus, many of the finds published in less accessible scattered (often regional) archaeological editions remained unknown to the zoological community. All of them represent a valuable source for elucidating the former distribution of one of the most widespread Pleistocene carnivores in the Balkans.

The chronostratigraphy (Table 1) follows CoHen et al. (2013): (1) Chibanian (Middle Pleistocene, 770,000-129,000 years BP); (2) Late Pleistocene (129,000-11,700 years BP) [BP = before present].

\section{RESULTS AND DISCUSSION}

\section{History of evidence}

The first published data on C. c. spelaea in the Bulgarian literature appeared in 1904 (Popov 1904). They were assigned to Hyaena spelaea by the eminent archaeologist and praehistorian Professor Rafail Popov (1876-1940). These finds were collected during his excavations in the Malkata (Tonûva) Cave near Belâkovec in the vicinity of Veliko Tărnovo, northern Bulgaria (Popov 1904, Anonymous 1906). These Bulgarian publications appeared a century after the world's first publication on the fossil hyaenid remains (CUVIER 1805).

Both papers give an exhaustive description of the hyenid bones found in the Palaeolithic deposits in the Malkata Cave - mandibles, upper praemolars, distal femur, two humeri, lower praemolars, canines, etc. They also provided measurements of some canines $-5 \mathrm{~cm}, 6 \mathrm{~cm}$ and $8 \mathrm{~cm}$ length.

DOCKNER (2006), without any reference, lists two Bulgarian sites - the Devetaškata and Morovica Caves. In the Bulgarian literature the cave hyena was also a subject of special interest concerning the Upper Palaeolithic rock art of Europe (Spassov \& STOYCHEV 2004). These authors conclude that the exterior of this carnivore was very close in appearance (coloration pattern) to the recent African spotted hyena, Crocuta crocuta crocuta (Erxleben, 1777). Conclusions about details in head morphology by DocKNER (2006), based on tomography of skulls, are also similar.

Until 1976, a total of ten localities of C. c. spelaea had been known in Bulgaria (NIKOLOV 1977). In 1980 their number increased to 12 (Nikolov 1983). After Beron et al. (2006), the fossils of the cave hyena were found in 11 Bulgarian caves. In one site (Tabaškata cave) the hyena fossils were identified as "Crocuta sp." (BERON et al. 2006), although they were also dated as Late Paleolithic.

It is worth mentioning that even in the comprehensive encyclopedic work on the Bulgarian caves by Beron et al. (2006), some hyena sites were omitted. For example, Hlebarov (2004) 


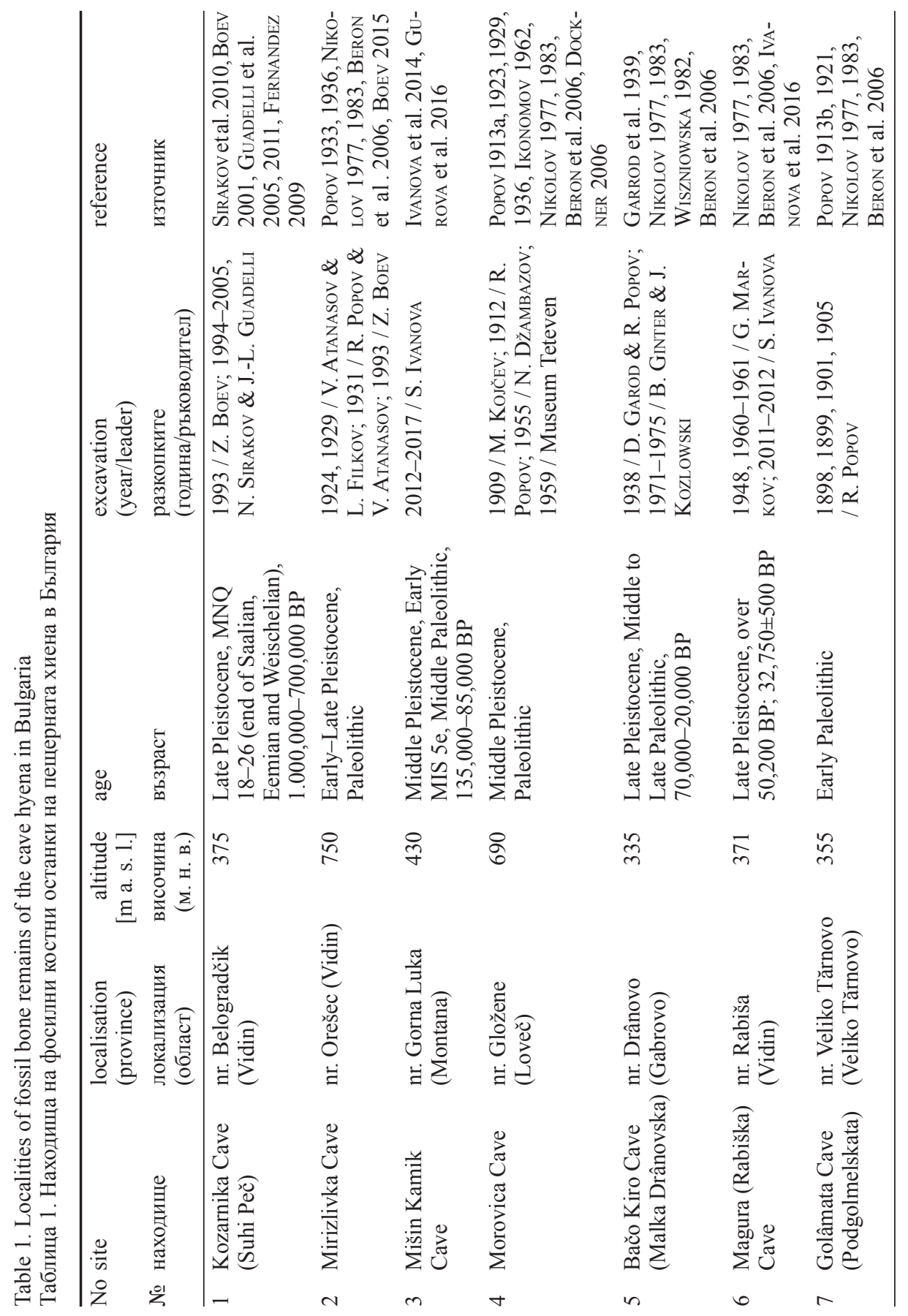




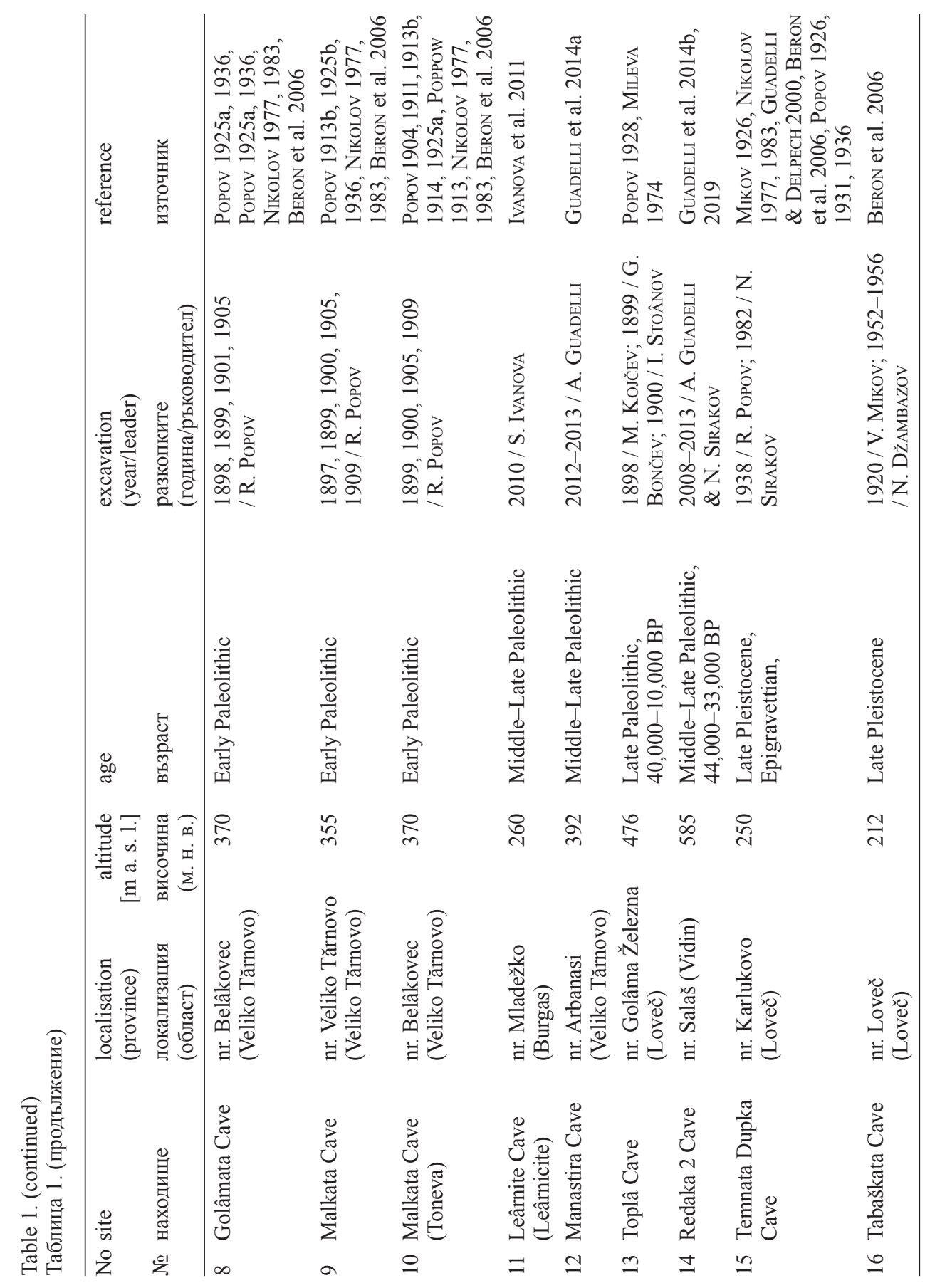




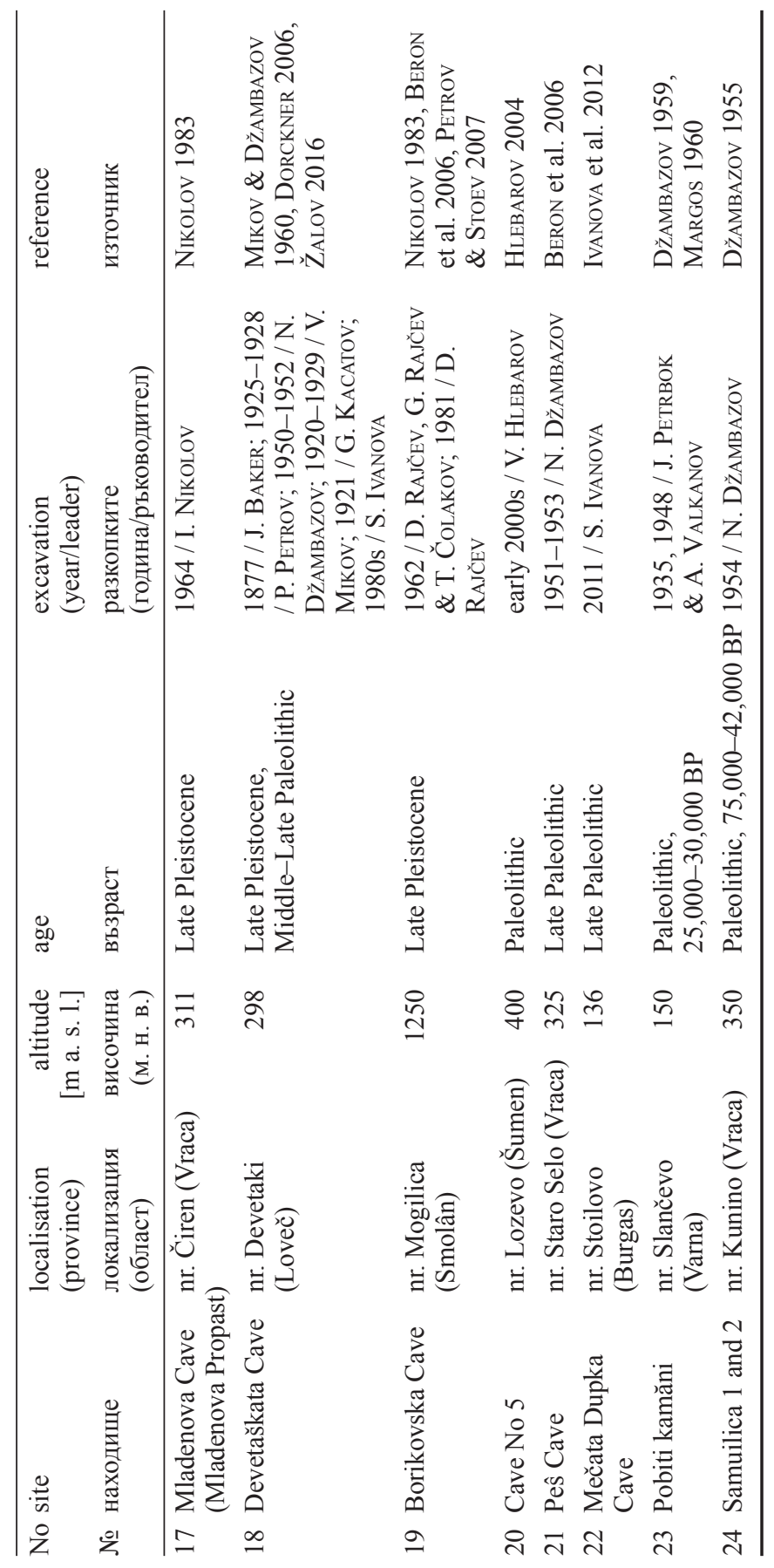


reported on a mandibular fragment with teeth from the Paleolithic layers of the Cave No. 5 (Šumen Province).

Concerning the number of the known sites of this carnivore in the country, until 2006 it was twice smaller than their number presented here (Table 1). New findings of remains of the cave hyena have been made also in the recent years. At present, preserved bone remains of the cave hyena are known from 24 caves. In fact they are spread mainly across northern Bulgaria. Among

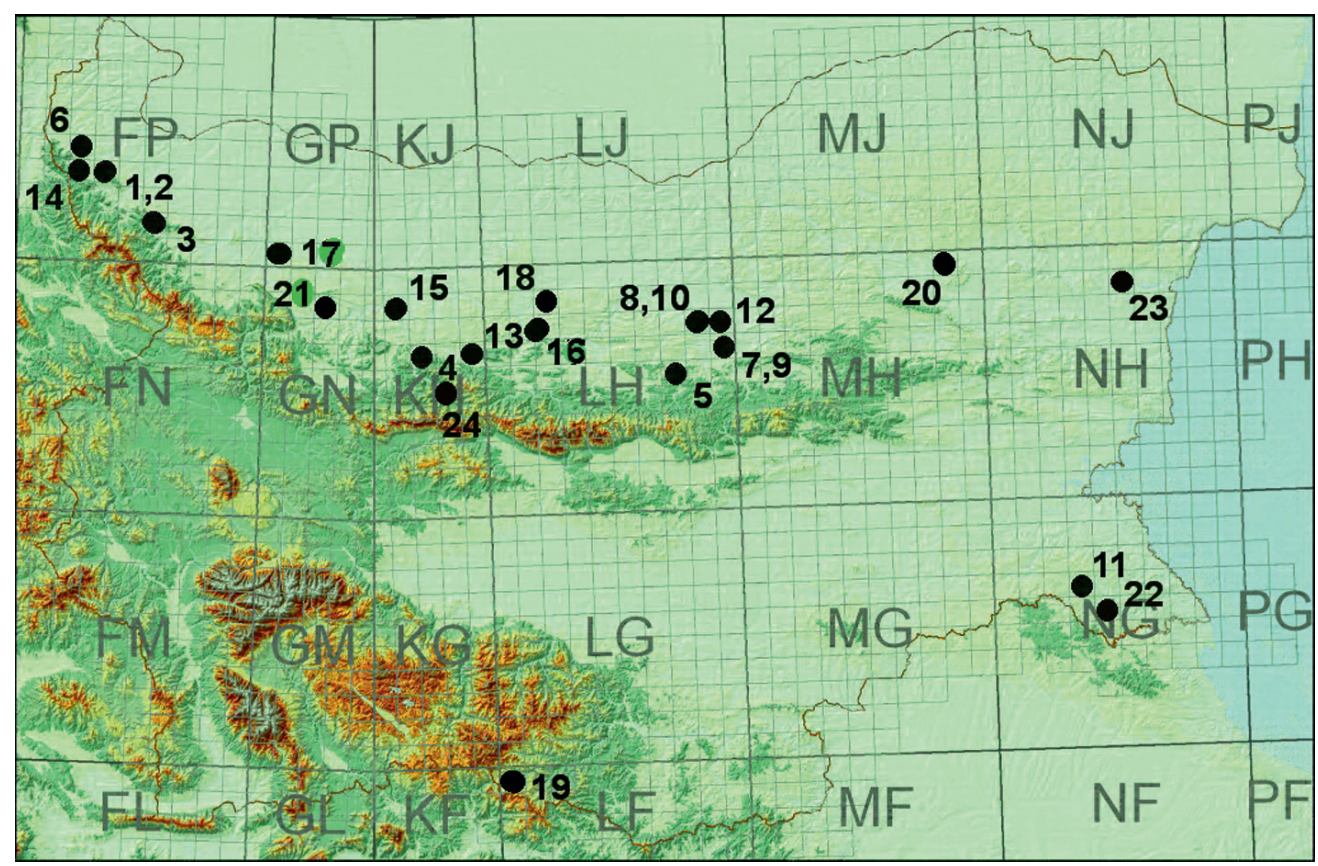

Fig. 1. Former distribution of Crocuta crocuta spelaea in Bulgaria. Numbers correspond to the list of localities in Table 1; Kozarnika (Suhi Peč) Cave (1), Mirizlivka Cave (2), Mišin Kamik Cave (3), Morovica Cave (4), Bačo Kiro (Malka Drânovska) Cave (5), Magura (Rabiška) Cave (6), Golâmata (Podgolmelskata) Cave (7), Golâmata Cave (8), Malkata Cave (9), Malkata (Toneva) Cave (10), Leârnite (Leârnicite) Cave (11), Manastira Cave (12), Toplâ Cave (13), Redaka 2 Cave (14), Temnata Dupka Cave (15), Tabaškata Cave (16), Mladenova Cave (Mladenova Propast Cave) (17), Devetaškata Cave (18), Borikovska Cave (19), Cave No 5 (20), Peš Cave (21), Mečata Dupka Cave (22), Pobiti kamăni (23), Samuilica Caves 1 and 2 (24).

Фиг. 1. Минало разпространение на Crocuta crocuta spelaea в България. Номерацията отговаря на находищата от Таблица 1; Пещера Козарника (Сухи Печ) (1), Миризливка (2), Мишин камик (3), Моровица (4), Бачо Киро (Малка дряновска пещера) (5), Магура (Рабишка пещера) (6), Голямата (Подголмелската) пещера (7), Голямата пещера (8), Малката пещера (9), Малката (Тонева) пещера (10), Пещера Леярните (Леярниците) (11), Пещера Манастира (12), Топля (13), Редака 2 (14), Темната дупка (15), Табашката пещера (16), Младенова пещера (Младенова пропаст) (17), Деветашката пещера (18), Бориковска пещера (19), Пещера № 5 (20), Пещера Пеш (21), Мечата дупка (22), Побити камъни (23), Самуилица 1 и 2 (24). 
them the Redaka 2 Cave showed to be the most abundant Bulgarian site in terms of fossils of the cave hyena and its exploration still continues. Remains of the cave hyena were found in all Early and Middle Paleolithic layers of this cave (SiRAKov 2020).

Unfortunately among these several dozens of publications, there are no papers dealing in details with C.c. spelaea fossils, its taphonomy, osteology, or paleoecology. All of them represent archaeological excavations and list various kinds of finds, incl. fossil bones of mammals (or of cave hyena in particular). Only in the last decade, mammalogists have been involved in some of these complex archaeological studies.

\section{Distribution}

Data in the map (Fig. 1) show three major regions that were more attractive for the cave hyena in the Pleistocene of Bulgaria. These regions represent parts of the major karst areas in the country. The Predbalkan Mts. in northern Bulgaria are the largest part of the former range of C. c. spelea in the country. It is a long belt across northern Bulgaria, $14,389 \mathrm{~km}^{2}$ in size, at the altitudes of 364-1490 m a. s. 1. Nineteen of the total of 24 sites are located there. The northern (Bulgarian part of the) Strandja Mts. and the southern part of the Western Rhodopes revealed only two and one sites, respectively. Nevertheless, findings in these mountain ranges are important, suggesting that the cave hyena was strictly dependent on karst landscapes even in the southern peripheries of its range. Similar rocky landscapes dominated around the Pobiti kamăni site (No. 23, Fig. 1).

Altitudinal distribution of the cave hyena in Bulgaria was confined between 136 and $1250 \mathrm{~m}$ a. s. 1. Sixteen sites (about 73\%) are located at 136-400 m a. s. 1. Almost all sites are situated below $750 \mathrm{~m}$ a. s. 1., with only one exception - the Borikovska Cave (1,250 m; Table 1). This could indicate that climatic conditions in the mountain habitats at higher altitudes were unfavourable for this animal. Caves in hilly landscapes and the foothills of the mountains seem to be most preferred, both in the inland parts of the country and along the Black Sea coast. The large ungulates were much more abundant in the plain open grasslands and hilly areas than on higher and forested mountain slopes.

The cave hyena was not a subject of special research in Bulgaria. Its fossil remains were usually found in the archaeological excavations in the caves inhabited by fossil man and this could also affect the available picture of the cave hyena distribution.

The fossil record of C. c. spelaea in Bulgaria proves the wide distribution of the species in the low-mountain rocky regions of the country. Its Pleistocene localities are concentrated in the Predbalkan Mts. (83\%), Strandja Mts. (8\%), the Western Rhodopes and southern Dobruja (4\% each). The sites were confined between 136 and $1250 \mathrm{~m}$ a. s. 1. All Bulgarian sites represent prehistoric human dwellings, which indicates competition between man and this carnivore for shelter and dwelling.

\section{РЕЗЮМЕ}

Статията обобщава всички разпръснати данни от последните 116 години за разпространението на късноплейстоценската западна пещерна хиена в България, част от които са непубликувани. Представени са данни за 22 фосилни находища (среден - късен плейстоцен) от 9 от 28-те области в страната. Фосилната летопис доказва широкото разпространение на вида в нископланинските части на страната. Плейстоценските му находища са концентрирани в Предбалкана ( 83 \%), Странджа (8 \%), Западните Родопи и Южна Добруджа (по 4 \%). Те са разположени между 136 и 1250 м. 
н. в. Около 75 \% от тях са разположени между 136 и 400 м н. в. Всички находища (с изкл. на едно) в България представляват някогашни човешки жилища - индикация за конкуренцията на човека с този хищник за убежища и подслон в пещерите.

\section{REFERENCES}

ANonymous, 1906: Prinos v izučavaneto na izmrâlata diluvialna hiena u nas [A contribution to the knowledge of the cave hyena in our country]. Priroda, 4: 70-71 (in Bulgarian).

BARYŠnIKov G., 1995: Peŝernaâ giena, Crocuta spelaea (Carnivora: Hyaenidae) iz paleolitičeskoj fauny Krima [Cave hyena, Crocuta spelaea (Carnivora, Hyaenidae) from the Paleolithic fauna of the Crimea]. Trudy Zoologičeskogo Instituta RAN, 263: 3-45 (in Russian, with a summary in English).

BARYSHNIKOV G. \& VereshChAgIN N., 1996: A brief review of Quaternary hyenas (Hyaenidae) of Russia and adjoining regions. Proceedings of the Zoological Institute, Russian Academy of Sciences, 270: 7-72.

Beron P., Daaliev T. \& Jalov A., 2006: Caves and Speleology in Bulgaria. Pensoft Publishers, Sofia, $507 \mathrm{pp}$.

Boev Z., 2001: Late Pleistocene birds from the Kozarnika Cave (Montana District; NW Bulgaria). Pp.: 113-128. In: Delchev P., Shanov S. \& Benderev A. (eds.): Karst. Vol. I. Proceedings of the First National Conference on Environment and Cultural Heritage in Karst. Sofia, 10.-11. 11. 2000. Earth and Man National Museum. Association of Environment and Cultural Heritage in Karst, Sofia, 199 pp.

Boev Z., 2015: Fossil and subfossil remains of birds and mammals from the Mirizlivka cave (Vidin Region - NW Bulgaria). ZooNotes, 75: 1-3.

Cohen K. M., Finney S. C., GibBard P. L. \& Fan J.-X., 2013: The ICS International Chronostratigraphic Chart. Episodes, 36: 199-204.

Cuvier G. L., 1805: Sur les ossemens fossiles d'hyenes. Annales du Museum d'Histoire Naturelle, 6: 127-144.

Diedrich C., 2014: Palaeopopulations of Late Pleistocene top predators in Europe: Ice Age spotted hyenas and steppe lions in battle and competition about prey. Paleontology Journal, 2014(106203): 1-34.

Diedrich C. G. \& ŽÁk K., 2006: Prey deposits and den sites of the Upper Pleistocene hyena Crocuta crocuta spelaea (Goldfuss, 1823) in horizontal and vertical caves of the Bohemian Karst (Czech Republic). Bulletin of Geosciences, 81(4): 237-276.

DimitriJević V., 2011: Late Pleistocene hyena Crocuta crocuta spelaea (Goldfuss, 1823) from Baranica Cave (Southeast Serbia): competition for a den site. Pp.: 69-84. In: ToskAn B. (ed.): Fragments of Ice Age Environments. Proceedings in Honour of Ivan Turk's Jubilee. Založba ZRC, Ljubljana, 280 pp.

DOCKNER M., 2006: Comparison of Crocuta crocuta crocuta and Crocuta crocuta spelaea through Computer Tomography. Unpubl. PhD Thesis. Department of Paleontology, University of Vienna, 68 pp.

DžAmbazov N., 1955: Novi danni kam proučvaneto na paleolita po dolinata na r. Iskar [New data on the Paleolithitic of the Iskar river valley]. Priroda $i$ Znanie, 1955(2): $23-24$ (in Bulgarian).

DžAmBazov N., 1959: Novi danni kam proučvaneto na paleolitnata kultura v Pobitite kamăni (Dikilitaš) [New data on the Paleolithitic culture of the Pobitite kamăni site (Dikilitaš)]. Priroda $i$ znanie, 1959(1): 20-23 (in Bulgarian).

FERNANDEZ P., 2009: Mammalian dynamics and palaeoecological analysis during the Pleistocene in Kozarnika Cave (Bulgaria). Pp.: 59-73. In: Gatsov I. \& Guadelli J.-L. (eds.): Saxa Loquuntur. Collected Works Honoring Nikolay Sirakov's 65th Anniversary. Avalon Publishing House, Sofia, 339 pp.

Garrod D., Howe B. \& Gaul J., 1939: Excavations in the cave of Bacho Kiro. Northeastern Bulgaria. Pp.: 46-126. In: MacCurdy G. G. (ed.): Bulletin of the American School of Prehistoric Research, No. 15. Office of the School, Old Lyne, $126 \mathrm{pp}$.

GrIČAN U. \& OvoDov N., 1978: Plejstocennovaâ giena v kamennoj lovuške [Pleistocene hyena in a stone trap]. Priroda, 12: 114-115 (in Russian).

Gromov I. \& Baranova G. (eds.), 1981: Katalog mlekopitâ̂sith SSSR (pliocen-sovremennost') [Catalogue of the Mammals of the Soviet Union (Pliocene-Present)]. Nauka, Leningrad, 456 pp (in Russian). 
Guadelli J.-L. \& Delpech F., 2000: Les Grands Mammiferes du debut du paleolithique superieur a Temnata. Pp.: 53-158. In: Ginter B., Kozlowski J. K., Guadelli J.-L. \& Laville, H. (eds.): Temnata Cave. Excavations in Karlukovo Karst Area, Bulgaria. Volume 2. Part 1. Jagellonian University, Cracow, 418 pp.

Guadelli J.-L., Sirakov N., Ivanova S., Sirakova S., Anastassova E., Courtaud P., Dimitrova I., Duabarska N., Fernandez P., Ferrier C., Fontugne M., Gambier D., Guadelli A., Iordanova D., Iordanova N., Kovatcheva M., Krumov I., Leblanc J.-C., Mallye J.-B., Marinska M., Miteva V., Popov V., Spassov R., TAneva S., Tisterat-Laborde N. \& Tsanova T., 2005: Une séquence du paléolithique inférieur au paléolithique récent dans les Balkans: la grotte Kozarnika à Orechets (Nord-Ouest de la Bulgarie). British Archaeological Reports, 1364: 87-103.

Guadelli J.-L., Sirakov N., Sirakova S., Ivanova S., Popov V., Fernandez P., Taneva S. \& Dimitrova I., 2011: Pr oučvaniâ na mogosl ojnata ar heol ogičeska sekvenciâ ot pl ejst ocena v peŝer a Kozarnika: ranen, sreden i kasen paleolit [Studies of the multilayer archaeological sequence from the Pleistocene in the Kozarnika Cave: Early, Middle and Late Plaleolithic]. Pp.: 23-28. In: Gurova M. (ed.): Arheologičeski otkritia i razkopki prez 2010 g. [Archeological Discoveries and Excavations in 2010]. Avangard, Sofia, $596 \mathrm{pp}$ (in Bulgarian).

Guadelli A., BoÂdžiev K., Guadelli J.-L., Crevrcoeur I. \& Karastô̂nova N., 2014a: Peŝtera Manastira, Velikotărnovsko [Manastira Cave, Veliko Tărnovo Province]. Pp.: 29-31. In: GurovA M. (ed.): Arheologičeski otkritiâ i razkopki prez 2013 g. [Archeological Discoveries and Excavations in 2013]. TDG Print, Sofia, 683 pp (in Bulgarian).

Guadelli A., Guadelli J.-L., Sirakov N., Krumov I. \& Mitov K., 2014b: Proučvaniâ na paleolita v peŝerata Redaka II, Belogradčiško [Investigation of the Paleolithic in the Redaka II Cave, Belogradčik Province]. Pp.: 30-31. In: KaBAKČIEva G. (ed.): Arheologičeski otkritiâ i razkopki prez 2013 g. [Archeological Discoveries and Excavations in 2013]. Aktiv Komers EOOD, Sofia, 911 pp (in Bulgarian).

Guadelli A., Guadelli J.-L., Simov N., Karastoânova N., Mitov K., Krumov I. \& Taneva S., 2019: Srednoi kasnopaleolitni otloženiâ v peŝera Redaka 2 [Middle and Late Paleolithic deposits in the Redaka 2 Cave]. Pp.: 7-9. In: Popov N. (ed.): Arheologičeski otkritiâ i razkopki prez 2018 g. [Archeological Discoveries and Excavations in 2018]. Bulged Ltd, Sofia, 787 pp (in Bulgarian).

Gurova M., Ivanova S., Spasov N., Hristova L., Krumov I., Verheydenn S., Marinova E. \& Dedov I., 2016: Proučvane na peŝerata Mišin Kamik - sezon 3 [Excavations at Mišin Kamik Cave: 2015 season]. Pp.: 56-59. In: Aladžov A. (ed.): Arheologičeski otkritiâ i razkopki prez 2015 g. [Archeological Discoveries and Excavations in 2010]. Multiptint, Sofia, 797 pp (in Bulgarian).

Hlebarov V., 2004: Peŝtera № 5 - žilisise na čoveka ot paleolita [Cave No. 5 - a Paleolithic human dwelling]. Bălgarski Drevnosti, 1: 5-6 (in Bulgarian).

Holekamp K.-E. \& Kolowski J. M., 2009: Family Hyaenidae (Hyenas). Pp.: 234-261. In: Wilson D. E. $\&$ Mittermeier R. A. (eds.): Handbook of the Mammals of the World. Volume 1. Carnivores. Lynx Edicions, Barcelona, $727 \mathrm{pp}$.

IкоNomov G., 1962: Peŝerite v rajona na gr. Teteven [Caves in the region of the town of Teteven]. Priroda, 1962(4): 113-116 (in Bulgarian).

Ivanova S., Krumov I., Spasov N., Hristova L., Makedonska J., Gurova M. \& Strait D., 2014: Razkopki v peŝerata Mišin Kamak, Čiprovsko [Excavations in the Mišin Kamak Cave, Čiprovci]. Pp.: 31-35. In: Gurova M. (ed.): Arheologičeski otkritiâ i razkopki prez 2013 g. [Archeological Discoveries and Excavations in 2013]. TDG Print, Sofia, 683 pp (in Bulgarian).

Ivanova S., Gurova M., Spasov N., Hristova L., Tzankov N., Popov V., Marinova E., Makedonska J., Smith V., Ottoni C. \& Lewis M., 2016: Magura Cave, Bulgaria: A multidisciplinary study of Late Pleistocene human palaeoenvironment in the Balkans. Quaternary International, 415: 86-108.

Kempe S., Al-Malabeh A., Döppes D., Frehat M., Henschel H.-V. \& Rosendahl W., 2006: Hyena caves in Jordan. Pp.: 201-212. In: Tsoukala E. S. \& RABeder G. (eds.): Scientific Annals of the School of Geology, Special Volume 98. Proceedings of the $12^{\text {th }}$ International Cave Bear Symposium. 2-5 November 2006, Thessaloniki and Ardea (Pella, Macedonia). Aristotle University of Thessaloniki, Thessaloniki, 318 pp.

Margos A., 1960: Čudnata kamenna gora [Wonderful Stone Forest]. Izdatelstvo Varna, Varna, 39 pp (in Bulgarian). 
Miкov V. 1926: Peŝteri i propasti meždu Iskar i Vit [Caves and chasms between the Iskar and Vit rivers]. Estestvoznanie i Geografiâ, 7-8: 236-249 (in Bulgarian).

Mikov V. \& DžAmbazov V., 1960: Devetaškata peŝera [Devetaškata Cave]. Bălgarskata akademiâ na naukite, Sofiâ, 200 pp (in Bulgarian).

Mileva L., 1974: Razvitie i razprostranenie na kvaternernata bozajna fauna u nas [Development and Distribution of the Quaternary Mammalian Fauna in Our Country]. Unpubl. MSc. Thesis. Sofijski Universitet "Sv. Kliment Ohridski", Sofiâ, 66 pp (in Bulgarian).

Nagel D., Rohland N. \& Hofreiter M., 2004: Phylogeography of the cave hyena (Crocuta crocuta spelaea): morphology versus genetics. In: MAUL L. \& KAHLKE R.-D. (eds.): Conference Volume. 18th International Senckenberg Conference. VI International Palaeontological Colloquium in Weimar. Late Neogene and Quaternary Biodiversity and Evolution: Regional Developments and Interregional Correlations. Terra Nostra, 2: 190.

NiKolov I., 1977: Pregled na peŝernata fosilna bozajna fauna v Bălgariâ i badesite problemi [Review of the cave fossil fauna of Bulgaria and close problems]. Pp.: 98-101. In: Dinev L., Panajotov T. \& Popov N. (eds.): Speleologiâ. Dokladi izneseni na speleoložkata konferencia, sastoala se na 10. 12.1976 g., organizirana ot Bălgarskata akademiâ na naukite i Bălgarskiâ turističeski sauz - Bălgarska federaciâ po peserno delo [Spelelogy. Proceedings of the Speleological Conference, Held on 10 December 1976, Organised by the Bulgarian Academy of Science, and Bulgarian Touristic Union-Bulgarian Speleological Federation]. Bălgarskata akademiâ na naukite, Sofiâ, 158 pp (in Bulgarian).

NIKOLOv I., 1983: Nâkoj beležki varhu peŝernata fosilna bozajna fauna v Bălgariâ [Some notes on the cave fossil mammalian fauna in Bulgaria]. Pp.: 215-218. In: Dinev L. (ed.): Cetvarta evropejska regionalna konferenciâ po speleologiâ, septemvri, 1980 [Fourth European Regional Conference on Speleology, September 1980]. Bălgarska federaciâ po pešterno delo, Sofiâ, 403 pp (in Bulgarian).

Petrov B. \& Stoev P., 2007: Podzemniât svât na peŝerite [Undergound World of Caves]. UNDP, Sofiâ, $82 \mathrm{pp}$ (in Bulgarian).

Popov R., 1904: Prinos kăm predistoriata na Bălgaria (peŝerite v Tărnovskia Dervent, seliŝeto Madara i peŝerite nad Šumen) [A contribution to the prehistory of Bulgaria (the caves of the Tărnovo Dervent, the settlement of Madara and the caves above Šmen]. Sbornik za Narodni Umotvorenia, 20: 1-27 (in Bulgarian).

Popov R., 1911: Malkata peŝera v Tărnovskiâ dervent [Malkata Cave in the Tărnovo Dervent]. Estestvoznanie, 3: 148-166 (in Bulgarian).

Popov R., 1913a: Razkopki v peŝerata Morovica [Excavations in the Morovica cave]. Bulletin de la Societe Archeologique Bulgare, 3: 263-290 (in Bulgarian).

Popov R., 1913b: Prinos kam diluvialnata fauna na Bălgariâ [A contribution to the Diluvial fauna of Bulgaria]. Spisanie na Bălgarskata Akademiâ na Naukite, 7: 115-142+8 plts (in Bulgarian).

Popov R., 1914: Malkata peŝera [Malkata Cave]. Bălgarski Turist, 1914(4): 57-60 (in Bulgarian).

Popov R., 1921: Peŝerata Golâma Lisca [Golâma Lisca Cave]. Estestvoznanie i Geografiâ, 2-3: 95-105 (in Bulgarian).

Popov R., 1923: Peŝernata mečka (Ursus spelaeus Blumb) [Cave bear (Ursus spelaeus Blumb)]. Estestvoznanie i Geografiâ, 6: 176-180 (in Bulgarian).

Popov R., 1925a: Belâkovskoto plato. Peŝeri i doistoričeski seliŝa [Belâkovsko Plateau. Caves and prehistoric settlements]. Izdaniâ na Narodniâ Muzej v Sofiâ, 3: 1-58 (in Bulgarian).

Popov R., 1925b: Novi nahodki ot predistoričeskiâ čovek v Bălgariâ [New findings of the prehistoric man in Bulgaria]. Priroda, 1925(3-4): 33-34 (in Bulgarian).

Popov R., 1926: Peŝerata Tamnata Dupka pri Karlukovo [Temnata Doupka Cave near Karlukovo]. Bălgarski Turist, 1926(1): 5-8 (in Bulgarian).

Popov R., 1928: Kultura i život na predistoričeskiâ čovek v Bălgariâ. Čast I. Kamenna epoha [Culture and Life of the Prehistoric Man in Bulgaria. Part I. Stone Epoch]. Bălgarski arhaeologičeski institut, Sofiâ, 64 pp (in Bulgarian).

Popov R., 1929: Doistoričeska Bălgariâ [Prehistorical Bulgaria]. Hristo Danov, Sofiâ, 76 pp (in Bulgarian). 
PoPov R., 1931: Temnata dupka - novo nahodiŝe ot paleolita v Bălgariâ [Temnata Dupka - a new locality of the Paleolithic in Bulgaria]. Izdaniâ na Narodniâ Arheologičeski Muzej v Sofiâ, 24: 1-148 (in Bulgarian).

Popov R., 1933: Peŝerata Mirizlivka. Prinos kam diluvialnata fauna i kulturata na diluvialniâ čovek [Mirizlivka Cave. A contribution to the diluvial fauna and the culture of the diluvial man]. Izdaniâ na Narodniâ Arheologičeski Muzej, 26: 1-74 (in Bulgarian).

Popov R., 1936: Fosilni i subfosilni životinski ostanki v izsledvanite do sega peŝeri na Bălgariâ [Fossil and subfossil animal remains in the caves of Bulgaria studied so far]. Izvestiâ na Bălgarskoto Peŝerno Družestvo, 1: 1-12 (in Bulgarian).

Poppow R., 1913: Die Ausgrabungen in der Höhle "Malkata Podlisza" bei die Dorfe Beljakovez, unweit der Stadt Tirnovo (Nordbulgarien). Praehistorischen Zeitschrift, 5(3-4): 449-460.

Rohland N., Pollack J., Nagel D., Beauval C., Airvaux J., Pä̈̈вo S. \& Hofreiter M., 2005: The population history of extant and extinct hyenas. Molecular Biology and Evolution, 22: 2435-2443.

Sirakov N., 2020: Sondage Explorations in the Redaka 2 Cave. URL: http://www.fastionline.org/excavation/micro_view.php?fst_cd=AIAC_2228\&curcol=sea_cd-AIAC_2712.

Sirakov N., Guadelli J.-L., Ivanova S., Sirakova S., Boudadi Maligne M., Dimitrova I., Fernandez P., Ferrier C., Guadelli A., Iordanova D., Iordanova N., Kovatcheva M., Krumov I., Leblanc J.-C., Miteva V., Popov V., Spassov R., Taneva S. \& Tsanova T., 2010: An ancient continuous human presence in the Balkans and the beginnings of human settlement in western Eurasia: A Lower Pleistocene example of the Lower Palaeolithic levels in Kozarnika Cave (Northwestern Bulgaria). Quaternary International, 223-224: 94-106.

Spassov N. \& Stoychev T., 2004: The presence of cave hyena (Crocuta crocuta spelaea) in the Upper Palaeolithic rock art of Europe. Historia Naturalis Bulgarica, 16: 159-166.

STINER M., 2004: Comparative ecology and taphonomy of spotted hyenas, humans, and wolves in Pleistocene Italy. Revue de Paléobiologie, 23: 771-785.

Suraprasit K., Jaeger J.-J., Chaimanee Y., Benammi M., Chavasseau O., Yamee C., Tian P. \& Panha S., 2015: A complete skull of Crocuta crocuta ultima indicates a late Middle Pleistocene age for the Khok Sung (northeastern Thailand) vertebrate fauna. Quaternary International, 374: 34-45.

Wiszniowska T., 1982: Carnivora. Pp.: 52-55. In: Kowalski K. (ed.): Excavation in Bacho Kiro Cave (Bulgaria). Final Report. Państwowe wydawnictwo naukowe, Warszawa, 172 pp.

ŽAlov A., 2016: Devetaškata peŝtera [Devetaškata Cave]. Priroda, 2016(2): 90-101 (in Bulgarian). 